Nigerian Journal of Physiological Sciences 23 (1-2): 37-40 @Physiological Society of Nigeria, 2008

Available online/abstracted at http://www.bioline.org.br/np; www.ajol.info/journals.nips; www.cas.org

\title{
HYPOGLYCAEMIC AND HYPOLIPIDAEMIC EFFECTS OF THE AQUEOUS LEAF EXTRACT OF MURRAYA KOENIGII IN NORMAL AND ALLOXAN - DIABETIC RATS
}

\author{
H. A.LAWAL ${ }^{1}$, M. K. ATIKU ${ }^{1}$, D. G. KHELPAI ${ }^{2}$ AND N. N. WANNANG ${ }^{2}$. \\ ${ }^{1}$ Department of Biochemistry, Bayero University, P.M.B. 3011, Kano, Nigeria \\ ${ }^{2}$ Department of Pharmacology, Faculty of Medicine, Bayero University, P.M.B. 3011, Kano, Nigeria
}

\begin{abstract}
Summary: The hypoglycaemic effect of aqueous leaf extract of Murraya koenigii was studied in normal and alloxan- induced diabetic rats. The extract was administered orally at $100 \mathrm{mg} / \mathrm{Kg}, 150 \mathrm{mg} / \mathrm{Kg}$ and 200 $\mathrm{mg} / \mathrm{Kg}$ bodyweight each to respective groups of animals (Groups I, II and III) for seven days. Group IV received normal saline and served as control for the normal rats. For the alloxan-induced diabetic rats, the same dosage pattern was administered to three groups of rats for seven days (Groups V, VI and VII) while group VIII which received normal saline served as control. At the various dose levels administered, the glucose lowering effect was more pronounced in the alloxan-diabetic rats than in control rats. When compared with chlorpropamide, the glucose lowering effect of aqueous extract of Murraya koenigii was significantly $(\mathrm{p}<0.05)$ lower at the dose levels administered in both normal and alloxan-diabetic rats.
\end{abstract}

Key Words: Murraya koenigii, Hypoglycaemia, diabetes mellitus, plasma glucose

\section{Introduction}

Diabetes mellitus is a metabolic disorder of multiple aetiology characterized by chronic hyperglycaemia with disturbances of carbohydrate, fat and protein metabolism resulting from defects in insulin secretion, insulin action or both. Management of this disease may include lifestyle modifications, diet, exercise, long - term use of oral hypoglycaemic agents or insulin therapy.

Since ancient times, plants have been an exemplary source of medicine. The search for plants with hypoglycaemic property is an area that draws attention of research workers globally. Grover et al. (2002) reviewed 45 of such plants and their products that have been mentioned/used in the Indian traditional system of medicine. Literature reports have indicated that the use of Momordica foetida (Olaniyi, 1980), Disocorea dumentorum (Iwu et al., 1990a), Garcina kola (Iwu et al., 1990b), etc as antidiabetic agents in Nigeria.

Murraya koengii is a small deciduous tree with very pungent aromatic leaves (curry leaf) belonging to the family Rutaceae of trees. The family includes plants throughout tropical zones on most continents and includes approximately 1500 genera and 1500 species. In Kano State, curry leaf is used traditionally as a stimulant, antidysenteric and for management of diabetes mellitus. Even though, literature reports elsewhere (Khan et al., 1995) indicate that Murraya koengii possess hypoglycaemic property, the plant has not been subjected to scientific investigation (in the context in which it is used) in Kano State. Therefore, this work is aimed at investigating the hypoglycaemic effect of aqueous extract of Murraya keonigii and its effect on serum lipid levels in normal and alloxan - diabetic rats.

\section{Materials and Methods}

Plants materials/preparation of the extract

Fresh leaves of the plant (Murraya koenigii) were obtained locally from a farmer in Kano metropolis. The leaf was identified by a staff of the Botany Unit, Bayero University, Kano. Aqueous leaf extract was prepared as described by Sofowora (1984). The fresh leaves were ovendried at $45^{\circ} \mathrm{C}$ for 3 days, ground into power and $20 \mathrm{~g}$ soaked in $300 \mathrm{ml}$ of distilled water overnight at room temperature. The filtrate obtained was evaporated to constant weight in a hot-air oven at $45^{\circ} \mathrm{C}$ for 4 days and the yield of the extract was approximately $60 \%$. The extract was weighed 
( $2 \mathrm{~g})$ and reconstituted in appropriate volume of distilled water before administration to the rats.

\section{Animals}

Adult male wistar rats weighing between 150- 200g, obtained from the National Veterinary Research Institute (NVRI), Vom, Plateau state, Nigeria were used. The animals were allowed free access to food and water. Grower's mash was used to feed the animals throughout the study period. The rats were divided into eight groups of five rats per group. Groups I, II, III were administered aqueous leaf extract of Murraya koenigii at dose levels of $100 \mathrm{mg} / \mathrm{kg}, 150 \mathrm{mg} / \mathrm{kg}$ and $200 \mathrm{mg} / \mathrm{kg}$ body weight respectively. Group IV received normal saline only and served as control for the normal rats.

Experimental diabetes was induced in the hyperglycaemic group with alloxan- (sigma) administered intraperitoneally at a dose of $100 \mathrm{mg} / \mathrm{kg}$. Rats were left for a period of four days prior to commencement of extract administration. Groups V, VI and VII were administered orally aqueous leaf extract of $M$. koenigii at dose levels of $100 \mathrm{mg} / \mathrm{Kg}, 150 \mathrm{mg} / \mathrm{Kg}$ and $200 \mathrm{mg} / \mathrm{Kg}$ bodyweight respectively. Group VIII received normal saline only and served as control for the alloxan - induced rats.

\section{Blood collection and Biochemical Analysis}

At the end of seven days period of extract administration, the rats were sacrificed. Blood samples were collected from the heart region directly into anticoagulant bottles and later plasma was collected after centrifugation. DIALAB ${ }^{\circledR}$ Diagnostic reagent kit was used to estimate plasma glucose concentration. Plasma triglyceride concentration was also determined using DIALAB® diagnostic reagent kit, while total cholesterol concentration was estimated using RANDOX® kit (catalogue No: $\mathrm{CH}$ 200). HDL - cholesterol was estimated in the supernatant left after precipitating very low density lipoproteins (VLDL) and low density lipoproteins (LDL) using magnesium chloride/phosphotungstic acid, was used to estimate plasma high density lipoprotein cholesterol (HDL - $\mathrm{CH}$ ) using RANDOX® kit (catalogue No: CH 200). LDL - Cholesterol was calculated by Friedwald's formula (Friedwald et al., 1972).

\section{Acute Toxicity}

Various doses $(80 \mathrm{mg} / \mathrm{Kg}, 400 \mathrm{mg} / \mathrm{Kg}$ and $2000 \mathrm{mg} / \mathrm{Kg}$ ) of aqueous leaf extract of $M$. koenigii were administered intraperitoneally to respective groups of rats. A control group were administered intraperitoneally normal saline. Rats were observed closely for toxic symptoms and behavioural changes for the first 2 hours of administration and mortality recorded within 24 hours.

\section{Statistical Analysis}

Fischer's ' $t$ ' test was used for statistical analysis.

Table 1: Effect of aqueous leaf extract of Murraya koenigii on serum glucose and serum lipids in normal rats after 7 days of administration

\begin{tabular}{lcccccc}
\hline Animals & $\begin{array}{c}\text { Dose (mg/Kg } \\
\text { bodyweight })\end{array}$ & $\begin{array}{c}\text { Glucose } \\
(\mathrm{mmol} / \mathrm{l})\end{array}$ & $\begin{array}{c}\mathrm{TG} \\
(\mathrm{mmol} / \mathrm{l})\end{array}$ & $\begin{array}{c}\mathrm{TC} \\
(\mathrm{mmol} / \mathrm{l})\end{array}$ & $\begin{array}{c}\mathrm{HDL}-\mathrm{CH} \\
(\mathrm{mmol} /)\end{array}$ & $\begin{array}{c}\mathrm{LDL}-\mathrm{CH} \\
(\mathrm{mmol} / \mathrm{e})\end{array}$ \\
\hline $\begin{array}{l}\text { Group I } \\
\mathrm{n}=5\end{array}$ & 100 & $4.19 \pm 0.13$ & $* 1.89 \pm 0.43$ & $2.37 \pm 0.22$ & $0.54 \pm 0.10$ & $1.46 \pm 0.09$ \\
$\begin{array}{l}\text { Group II } \\
\mathrm{n}=5\end{array}$ & 150 & $* 3.80 \pm 0.13$ & $2.14 \pm 0.43$ & $1.73 \pm 1.08$ & $0.46 \pm 0.35$ & $0.84 \pm 0.66$ \\
$\begin{array}{l}\text { Group III } \\
\mathrm{n}=5\end{array}$ & 200 & $* 3.27 \pm 0.13$ & $3.22 \pm 0.97$ & $4.31 \pm 0.78$ & $* 1.19 \pm 0.10$ & $2.48 \pm 0.51$ \\
$\begin{array}{l}\text { Group IV } \\
\mathrm{n}=5\end{array}$ & - & $4.45 \pm 0.26$ & $3.39 \pm 0.38$ & $3.23 \pm 1.94$ & $0.73 \pm 0.33$ & $1.82 \pm 1.54$ \\
\hline
\end{tabular}

Results are mean \pm standard deviation, $n=$ number of animals. *significantly different from controls at $p$ $<0.05$ 
Table 2: Effect of aqueous leaf extract of Murraya koenigii on serum glucose and serum lipids in alloxaninduced rats after 7 days of administration

\begin{tabular}{|c|c|c|c|c|c|c|}
\hline Animals & $\begin{array}{c}\text { Dose } \\
\text { (mg/Kg } \\
\text { bodyweight) }\end{array}$ & $\begin{array}{l}\text { Glucose } \\
(\mathrm{mmol} / \mathrm{l})\end{array}$ & $\begin{array}{c}\text { TG } \\
(\mathrm{mmol} / \mathrm{l})\end{array}$ & $\begin{array}{c}\mathrm{TC} \\
(\mathrm{mmol} / \mathrm{l})\end{array}$ & $\begin{array}{c}\mathrm{HDL}-\mathrm{CH} \\
(\mathrm{mmol} / \mathrm{l})\end{array}$ & $\begin{array}{c}\mathrm{LDL}-\mathrm{CH} \\
(\mathrm{mmol} / \mathrm{e})\end{array}$ \\
\hline $\begin{array}{l}\text { Group V } \\
n=5\end{array}$ & 100 & $* 3.27 \pm 0.12$ & $4.89 \pm 0.38$ & $4.10 \pm 0.94$ & $0.61 \pm 0.30$ & $2.50 \pm 0.75$ \\
\hline $\begin{array}{l}\text { Group VI } \\
\mathrm{n}=5 \\
\text { Group VII }\end{array}$ & 150 & $* 2.75 \pm 0.23$ & $4.14 \pm 0.50$ & $5.60 \pm 0.94$ & $0.81 \pm 0.30$ & $3.97 \pm 0.59$ \\
\hline $\begin{array}{l}n=5 \\
\text { Group VIII }\end{array}$ & 200 & $* 2.23 \pm 0.13$ & $2.64 \pm 0.14$ & $4.31 \pm 1.69$ & $0.73 \pm 0.30$ & $3.05 \pm 1.36$ \\
\hline $\mathrm{n}=5$ & - & $4.32 \pm 0.23$ & $4.18 \pm 0.58$ & $5.17 \pm 1.12$ & $0.92 \pm 0.12$ & $3.63 \pm 1.45$ \\
\hline
\end{tabular}

Table 3: Comparison of the glucose lowering effect of aqueous leaf extract of Murraya koenigii between normal and alloxan - diabetic rats

\begin{tabular}{lcccccc}
\hline Animals & $\begin{array}{c}\text { Group I } \\
\mathrm{N}\end{array}$ & $\begin{array}{c}\text { Group V } \\
\text { ALD }\end{array}$ & $\begin{array}{c}\text { Group II } \\
\mathrm{N}\end{array}$ & $\begin{array}{c}\text { Group VI } \\
\text { ALD }\end{array}$ & $\begin{array}{c}\text { Group III } \\
\mathrm{N}\end{array}$ & $\begin{array}{c}\text { Group VII } \\
\text { ALD }\end{array}$ \\
\hline $\begin{array}{l}\text { Glucose } \\
(\mathrm{mMol} / \mathrm{L})\end{array}$ & $4.19^{*} \pm 0.13$ & $3.27^{*} \pm 0.12$ & $3.80^{*} \pm 0.13$ & $2.75^{*} \pm 0.23$ & $3.27^{*} \pm 0.13$ & $2.23 \pm 0.13$ \\
\hline
\end{tabular}

Results are mean \pm standard deviation, $n=$ number of animals. *significantly different at $p<0.05 N=$ normal, ALD $=$ alloxan-diabetic

\section{Results and Discussion}

Table 1 presents the effect of aqueous extract of $M$. keonigii on plasma glucose and serum lipids in normal rats after seven days of administration. Plasma glucose levels decreased in a dose - dependent manner from Group I to Group III and the levels were lower than the level in the control group (Group IV). The differences in plasma glucose levels between Groups II, III and Group IV (control) were statistically significant $(\mathrm{P}<0.05)$. The difference in the plasma triglyceride level between Group I and Group IV was also statistically significant $(\mathrm{P}<$ 0.05). Plasma TC, HDL $-\mathrm{CH}$, and $\mathrm{LDL}-\mathrm{CH}$ levels did not differ in any clear trend between the groups.

In alloxan - diabetic rats, the aqueous extract of $M$. keonigii had the same effect on plasma glucose levels as in normal rats (Table 2). Plasma glucose levels decreased significant $(\mathrm{P}$ $<0.05)$ between Group V, VI, VII and Group VIII (control). Plasma triglyceride differed significantly $(\mathrm{P}<0.05)$ between Group VII and Group VIII (control). At the dose levels administered, the glucose lowering effect of aqueous extract of Murraya keonigii was significantly higher $(\mathrm{P}<0.05)$ in alloxan diabetic rats than in normal rats (Table 3 ). No mortality was recorded during acute toxicity study up to a dose of $2000 \mathrm{mg} / \mathrm{Kg}$ (Table 4).

Table 4: Data on mortality in rats after acute treatment with aqueous leaf extract of $M$. koenigii

\begin{tabular}{lll}
\hline $\begin{array}{c}\text { Dose (mg/Kg } \\
\text { bodyweight) }\end{array}$ & No. of rats & Mortality \\
\hline Control & 4 & 0 \\
80 & 4 & 0 \\
400 & 4 & 0 \\
200 & 4 & 0 \\
\hline
\end{tabular}

The findings of this study suggest that Murraya keonigii aqueous leaf extract possesses hypoglycaemic activity in normal and alloxan induced diabetic rats. This result agrees with earlier reports (Khan et al., 1995; Grover et al., 2002 and Kesari et al., 2005). However, this result contradicts the report of Adebayo et al. (2004) which refuted the antidiabetic ethnomedical claim of $M$. keonigii. Although, the extract showed antidiabetic properties, its activity was less than that of chlorpropamide at all doses administered. Therefore, the plant extract cannot be used as a substitute for conventional antidiabetic drugs. 
It has been suggested that $M$. koenigii acts by decreasing glycogenesis and gluconeogenesis (Khan et al., 1995). However, characterization of the active principle responsible for the hypoglycaemic activity of $M$. keonigii has not yet been done. As no mortality was recorded within 24 hours during the acute toxicity test, $\mathrm{LD}_{50}$ could not be calculated. The non - toxic effect of the aqueous leaf extract of M. koenigii (Table 4) lend support to the widespread use of the plant as a spice for food flavouring. It is also interesting to note that the glucose lowering effect of aqueous leaf extract of M. koenigii was higher in alloxan induced diabetic animals than in normoglycaemic animals (Table 3). This finding may form a basis for the inclusion of $M$. koenigii as a spice in the dietary management of diabetes mellitus. However, this postulate is open for further investigation.

\section{References}

Adebajo, A. C., Olayiwola, G., Verspohl, J. E., Iwalewa, E. O., Onisore, N. A., Bergentbal, D., Kumar, V. and Adesina, S. K. (2004). Evaluation of the ethnomedical claims of $M$. koenigii. Pharmaceutical Biol., 42(8), 610.

Freidwald, W. T., Levy, R. I. and Fredrickson, D. S. (1972). Estimation of the concentration of low-density lipoprotein cholesterol in plasma without use of the preparative ultracentrifuge. Clin. Chem. 18, 499 - 502.
Grover, J.K., Yadev, S. and Vats, V. (2002). Medicinal plants of India with antidiabetic potential. J. Ethnopharmacol. 81(1), 81 100.

Iwu, M. M., Okunji, C. O., Akah, P., Tempesta, M. S. and Corley, D. (1990a). Dioscoretine. The hypoglyceamic principle of Dioscorea dumentorum. Planta Medicine, 56, 119 120.

Iwu, M. M., Igboko, C. O., Okunji, C. O. and Tempesta, M. S. (1990b). Antidiabetic and aldose reductase inhibiting activities of biflavonones of Garcinia kola. J. Pharm. Phamacol. 42, 290 - 292.

Khan, B. A., Abraham, A. and Leelamma, S. (1995). Hypoglycaemic action of M. keonigiii (curry leaf) and Biasica juncea (mustard). Mechanism of action. Indian J. Biochem. Biophys, 32(2), 106 - 108.

Narendhirakannan, R. T., Subraimanian, S. and Kardasawamy, M. (2005). Mineral content of some medicinal plants used in the treatment of diabetes mellitus. In: Biological Trace Element Research, Vol. 103, Issue No. 2, pp $109-116$.

Olaniyi, A. A. (1980). 7 hydroxyfreidel - 6- 7 one from Momordica foetida. Planta Medicine 40, 303 - 305.

Sofowora, A. (1984). Medicinal Plants and Traditional Medicine in Africa. John Wiley Publishers, New York. $2^{\text {nd }}$ edition. pp 128 132. 